\section{Charles Turner Thackrah in the Agitation for Factory Reform}

\author{
GEORGE ROSEN
}

Habent sua fata libelli! And in many instances the thought is equally applicable to the men who wrote them. As a case in point consider the historical fate of Charles Turner Thackrah, surgeon of Leeds. His name occurs sporadically in histories of medicine. Usually, it is absent from the large general medical history, but may be found in monographs concerned with the development of public health or occupational medicine. Even in these, references to Thackrah are brief. Yet in the opinion of John Simon (1897) " one very important new line of thought in Preventive Medicine was opened for England in 1831, by Mr. C. Turner Thackrah, a surgeon of Leeds, who in that year published a work ... on The Effects of Arts, Trades and Professions, and of civic states and habits of living, on Health and Longevity ... . By his eminently trustworthy book, he, more than fifty years ago, made it a matter of common knowledge, and of State responsibility, that, with certain of our chief industries, special influences, often of an evidently removable kind, are apt to be associated, which, if permitted to remain, give painful disease and premature disablement or death to the employed persons ". 1 Clearly, Thackrah deserves to be better known.

Charles Turner Thackrah was born in Leeds on May 22, 1795..$^{2}$ Although destined by his mother for the Church, he was not interested in becoming a clergyman, and eventually decided to enter the medical profession. In 1811 , he was apprenticed to $\mathrm{Mr}$. O. Brooke, a surgeon of Leeds, with whom he studied for three years.

Even at this early period Thackrah already exhibited the devotion to duty and desire for knowledge which were to characterize his entire career. For example, in 1812, while carrying out the laborious duties of an apprentice, he found time to read thoroughly 25 books on medicine, history, and general knowledge, and to study 38 partially. During the next few years his reading increased extensively, shifting almost exclusively to professional subjects. In line with this passionate desire for knowledge is Thackrah's resolution of $1815^{\text {" }}$ to consume in sleep not more than eight hours in twentyfour, unless in case of sickness or disturbed rest, and to make himself acquainted each day with the nature and treatment of some disease". Undoubtedly related to

1. Simon, John (1897). English Sanitary Institutions, 2nd ed., pp. 125-127. Smith, Elder and Co., London.

2. The chief source for Thackrah's biography is H. Y. Whytehead (1834) Biographical Memoir, in C. Turner Thackrah An Inquiry into the Nature and Properties of the Blood in Health and Disease, pp.9-20, new and enlarged edition, Longman, Rees, Orme, London.

Confirmatory information on several points, particularly on Thackrah's relation to the Leeds medical school, is presented by J. Ingham Ikin (1851), "On the progress of public hygiene and sanitary legislation in England, and the advantages to be derived from their further extension", Provincial Medical and Surgical Journal, p. 538 . this resolve is the practice initiated by Thackrah about this time of keeping records of medical cases, a practice followed constantly in his later career.

Following the termination of his apprenticeship, Thackrah, in 1814, enrolled as a student at the Leeds Infirmary. His medical education was completed at London, where he spent the winter of 1815-16 in attendance at Guy's Hospital. In October, 1815, he became a member of the Physical Society at Guy's. Thackrah was exceedingly diligent in his attendance at lectures and anatomical exercise, and it is said that Sir Astley Cooper took special note of him. In his diary he recorded that he usually applied himself to his studies from seven in the morning to half-past eleven at night. It is not entirely surprising that Thackrah contracted an internal ailment, which produced painful and profuse diarrhoea, from which he suffered intermittently for the rest of his life.

In the spring of 1816 he passed the qualifying examinations at Apothecaries' Hall and at the College of Surgeons. At the same time, Thackrah won a prize offered by the Physical Society of Guy's with an essay on diabetes. He then returned to Leeds where early in 1817 he set himself up in practice. Election to the position of town surgeon improved Thackrah's professional position, and his practice began to develop. It seems plausible to suggest that Thackrah's interest in the social aspects of medicine, especially those related to occupation, was stimulated by the patients and the medical problems encountered in his capacity of town surgeon. Further stimulation in this direction very likely resulted from a request to Thackrah by the managing committee of the Leeds workhouse that he investigate lodging-houses for the poor. The report which he presented showed in striking fashion the miserable and unhygienic conditions existing in these establishments, and led to measures aimed at improving the situation.

At the same time, while carrying on a growing practice, and dealing with health matters of concern to the community, Thackrah did not neglect the scientific basis of medicine. His interest in anatomy, physiology, and pathology continued unabated, and in 1817 he began to investigate the nature and properties of blood. Based on these studies, he prepared the monograph, $A n$ Inquiry into the Nature and Properties of the Blood, in Health and Disease, which appeared in 1819. Before its publication this work had won for its author a prize given annually by Sir Astley Cooper to his students for the best dissertation on a subject proposed by himself.

In addition to his other interests, Thackrah had a lively concern for the problems of medical education. As early as 1820 he joined several other young physicians in arranging to give to their pupils a series of lectures on various branches of medicine. It is interesting to note that his own students received exercises in the classics and in English composition, in addition to exercises in drawing up necropsy reports and taking notes on medical cases. This profound and active interest in medical 
education led Thackrah early in $\mathbf{1 8 2 6}$ to consider the formation of an anatomical school ; and in May 1827, he completed his first lecture course on anatomy. According to Dr. Ikin, his fellow-townsman, this was the "first public course of anatomical lectures" in Leeds. ${ }^{3}$ It was followed by a second series of lectures in the spring of 1828 ; but despite these efforts his applications to the College of Surgeons and to Apothecaries' Hall to have his certificates to students admitted were rejected. In 1831, however, Thackrah's ideas on medical education were realized when he, together with several other physicians established the Leeds Medical School. ${ }^{4}$ During the sessions of 1831-32 and 1832-33 he lectured at the school on anatomy, physiology, pathology, and surgery.

The year 1831, however, was important in Thackrah's career for still another development. In this year he published the first edition of his pioneer work, The Effects of Arts, Trades and Professions.... on Health and Longevity. The reception accorded this work by the medical profession and the general public was exceptionally favourable. The first edition was soon exhausted, and a second, enlarged edition appeared in 1832. Sometime around 1824, Thackrah had begun to study how manufacturing processes affected the health of workers. As physician to the Leeds Infirmary, he had numerous opportunities to observe disordered states of health in various kinds of workers.

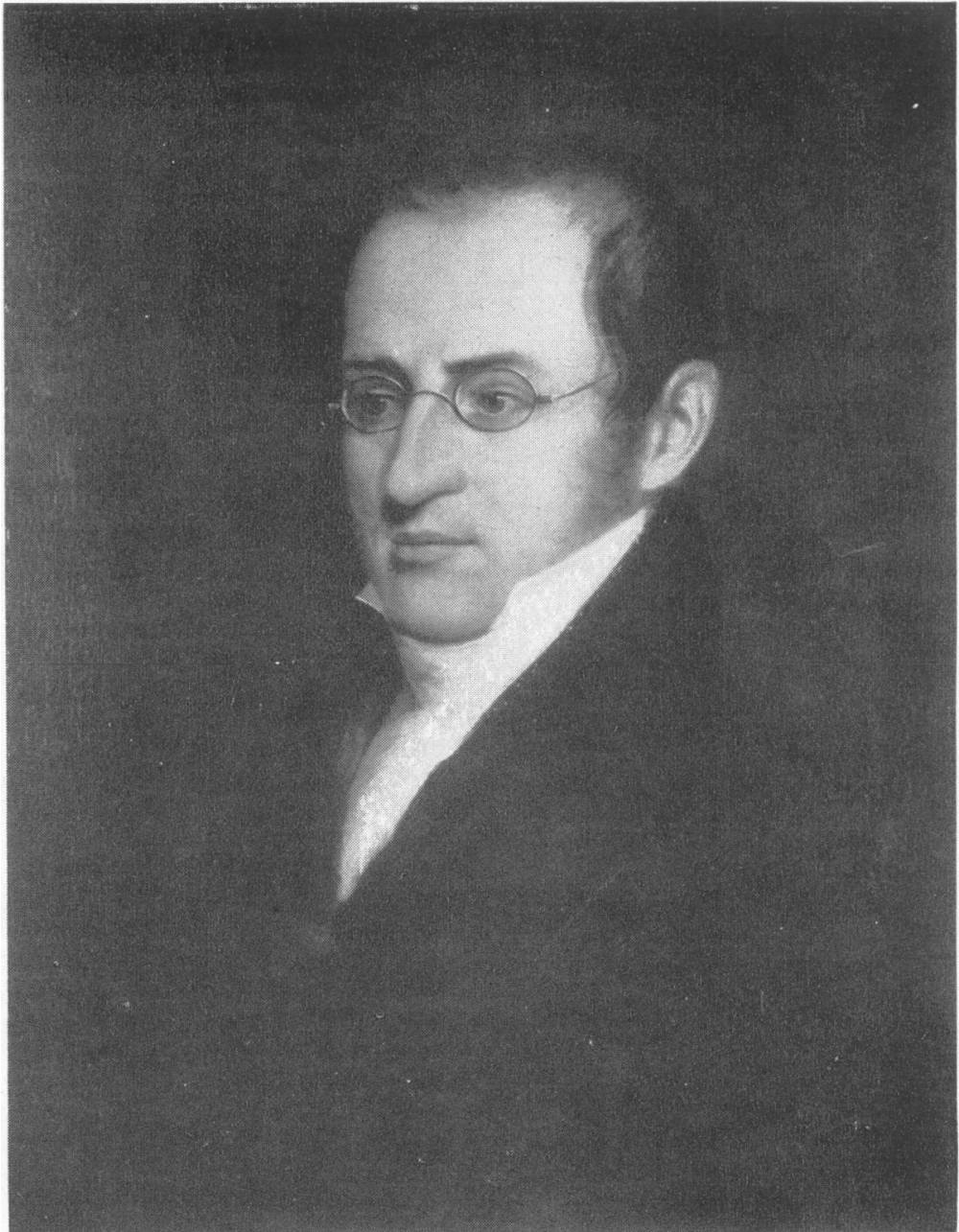

Charles Turner Thackrah

Reproduced b. kind perinission of the Board of Management of the Genera i Infir:nary at Leeds.
" Myself and my pupils", he pointed out, "have personally and carefully inspected the state of the agencies believed to be injurious, conversed on the subject with masters, over-lookers, and the more intelligent workmen, and obtained many tables illustrating the character of the disorders prevalent in the several kinds of employ. From these sources collectively, and my own observations in practice, I have drawn up statements, which, though avowedly imperfect, must, I conceive, approach to the truth." 5

Thackrah's object was to attract public attention to the problem of preventable ill-health as related to

3. Ikin, J. Ingham (1851). Ibid., p. 539.

4. Ikin makes the following comment: "I must also, in bare justice, couple his name with the earliest founders of provincia medical schools ... his exertions ultimately gave origin to the more effective organization of the Leeds Medical School ..." See op. cit. p. 539.

5. Thackrah, C. Turner (1832). The Effects of Arts, Trades, and Professions, and of Civic States and Habits of Living, on Health and Longevity, p. 6. 2nd ed., greatly enlarged. Orme, Brown, Green, and Longman, London. occupation and similar factors so that action could be taken to deal with them. In this aim he succeeded better than he had perhaps anticipated. The great political uprising which culminated in the Reform Act of 1832 was nearing its height. At the same time, the industrial workers were organizing not only for political agitation but as well for improvement of conditions in the factories. Their chief demand was the restriction of hours of labour specifically for children, and the publication of Thackrah's book came at the right moment in support of this social reform.

Leading the campaign in the West Riding was Richard Oastler, who in 1830 had set out to abolish "Yorkshire slavery", that is, child labour. Oastler had come to know Thackrah soon after he had begun to agitate for factory reform, and had been assured of his wholehearted support in the endeavour to restrict child labour. ${ }^{6}$

6. Driver, Cecil (1946). Tory Radical. The Life of Richard Oastler, p. 73. Oxford University Press, New York. 
In March, 1831, Oastler wrote a letter to the Leeds Mercury commenting on the factory controversy, in which he made use of Thackrah's recently published book. According to Thackrah :

"No man of humanity can reflect without distress on the state of thousands of children, many from six to seven years of age, roused from their beds at an early hour, hurried to the mills and kept there with an interval of only forty minutes till a late hour at night ; kept moreover in an atmosphere impure not only as the air of a town, not only as defective in ventilation, but as loaded also with noxious dust."

Thenceforth, Thackrah and his book were enlisted in the continuing campaign to improve working conditions in factories. As the movement for factory reform developed, it became evident that the work of the children was inextricably bound up with that of the adults. Consequently, the establishment of a reasonable working day for children involved also the regulation of adult labour. In April, 1831, Oastler issued a manifesto To the Working Classes of the West Riding in which he formulated the clear-cut objective of the 10-hour day, and set in motion a movement which was to have incalculable consequences for British social politics.

Toward the end of 1831, Michael Sadler, recently elected to Parliament, introduced a Ten Hours Bill. Proponents of the measure realized the immediate need for mobilizing public opinion on its behalf, and planned to hold a series of meetings to rouse the workers and the general public. The third of these meetings was held at Leeds in January, 1832. On the platform was a distinguished group of notables, including opponents as well as advocates of Sadler's bill. Among them was Thackrah, ${ }^{7}$ who is reported to have presented the case for regulation of working hours with vigour and realism. $\mathrm{He}$ buttressed his presentation by citing the cases of some of his child patients. Was it any wonder, with such conditions, he asked, that the coming generation was unable to resist the onslaught of disease ?

On March 16, 1832, Sadler in a brilliant three-hour speech moved the second reading of his bill. His presentation was solidly grounded in logic and fact. As part of the evidence to prove the need for legislation, he described the shocking working conditions in many factories and their effect on the worker's health. In support of his contention, Sadler cited the evidence of medical men with experience in this field, among them Thackrah. Sadler had received a copy of Thackrah's work on the

7. Driver, Cecil (1946). Ibid., pp. 135-136. effects of occupation on health and disease, and he made good use of it. ${ }^{8}$

Unfortunately, Thackrah did not live to see the ultimate triumph of the cause he had espoused. Despite poor health, he continued to labour indefatigably on medical and public health problems. The prevalence of cholera in 1831-32 led him to visit Newcastle and Gateshead, and resulted in a pamphlet on the disease which was favourably received by the profession. Thackrah also continued the preparation of a new edition of his monograph on the blood. In 1833, however, the condition of his health began to deteriorate rapidly. The gastro-intestinal condition with which Thackrah was afflicted was complicated by pulmonary disease, and he died on May 23, 1833.

Despite his premature death, Charles Turner Thackrah left an indelible imprint on the social and medical development of Great Britain. Writing in 1851 on the progress of public health in England, Ikin pointed out that

"The political promoters and agitators for the promotion of factory legislation, though often led astray by their zeal and enthusiasm, deserve the gratitude of their country ; and, in the progress of this, to us... exciting question, the aid, co-operation, and testimony of the members of the medical profession tended more than any other influence to compel the interference of the Legislature.", 9

In this company Thackrah occupies not only an honoured place; he stands out far ahead of his contemporaries. Not only did he recognize the social responsibility of the physician to his community and act on it, but he also laid the foundation for the study of occupational health in Great Britain. His work continued to be used after his death by all those interested in dealing with the health problems raised by the new industrial civilization. ${ }^{10}$ Thackrah's work was well conceived, based on wide research, and above all imbued with social consciousness. He crowded much into his short life, but it was pregnant with profound meaning for the future.

8. I have a copy of the 1832 edition bearing the inscription: “ M. T. Sadler Esq., M.P. with respectful compliments of the author". 9. Ikin, J. Ingham (1851). Ibid., p. 539.

10. For example, P. Gaskell (1836) Artisans and Machinery, John W. Parker, London; John Wade (1835) History of the Middle and Working Classes, 3rd ed., Effingham Wilson, London ; Benjamin W. McCready (1837) On the Influence of Trades, Professions, and Mccreadions in the United States, in the Production of Disease, New Occupations in the United States, in the Production of Disease, New
York. [Orig. publ. in Trans. med. Soc. st. New York, 3, Appendix p. 25.] 